\title{
DETERMINAN INTENSITAS KERAWANAN PANGAN SERTA HUBUNGANNYA DENGAN FOOD COPING STRATEGIES DAN TINGKAT KECUKUPAN ENERGI DI KECAMATAN RAWAN DAN TAHAN PANGAN
}

\author{
(Determinant of Food Insecurity Intensity and correlation with Food Coping Strategis and \\ Household Energy Intake ) \\ Ikeu Tanziha ${ }^{1 *}$, Hardinsyah ${ }^{1}$ dan Mewa Ariani ${ }^{1}$ \\ ${ }^{1 *}$ Alamat korespondensi: Departemen Gizi Masyarakat, Fakultas Ekologi Manusia, Institut Pertanian \\ Bogor, Bogor 16680. Telp: 0251-8621258; Fax: 0251-8622276; Email: ikeu_jamilah@yahoo.com \\ 1 Departemen Gizi Masyarakat, Fakultas Ekologi Manusia, Institut Pertanian Bogor, Bogor 16680.
}

\begin{abstract}
The objective of the study was to analyze the correlation among intensity of food insecurity and food coping strategy with energy intake and child nutritional status. The study design was a crosectional study. Research was conducted in Pandeglang Distric, in April - May - July 2009. A purposive sampling were applied to select 220 households. The data collected include socio economi, food coping strategy, intensity of food insequrity and, food intake. The Rank Sperman and Pearsons test were applied to analyse correlation between variable socio economic, food insecurity intensity, food coping strategy and energy intake. Logistic regression was used to analyze determinant of food insecurity intensity. Multiple regression was used to analyse determinant of energy intake. The results showed that there were significant correlatin between intensity of food insequrity with household expenditure, and food coping startegy. Determinan of food insecurity intensity were household expenditure per capita $(O R=0.033)$ and type of food insecurity program $(O R=6.664)$. determinan of energy intake were food insecurity intensity, household expenditure percapita and household size.
\end{abstract}

Key words: Intensity of food insecurity, food coping strategy, and energy intake

\section{PENDAHULUAN}

Bangsa Indonesia saat ini tengah dihadapkan kepada masalah ketahanan pangan yang sangat serius. Secara umum, selain permasalahan utama yang dihadapi adalah sistem ketersediaan pangan di Indonesia yang belum mampu mengejar peningkatan kebutuhan pangan penduduk, akses pangan penduduk pun merupakan hal yang cukup mengkhawatirkan.

Jumlah penduduk miskin di Indonesia masih tinggi, meskipun telah terjadi penurunan dari $17.75 \%$ pada tahun 2006 menjadi $15.42 \%$ pada tahun 2008 , namun persentase ini masih jauh dari target RPJMN pada tahun 2009 yaitu $9 \%$. Kondisi ini berdampak pada rentannya penduduk terhadap rawan pangan. Data menunjukkan telah terjadi peningkatan penduduk dalam kondisi sangat rawan pangan dari 5,11 juta jiwa pada tahun 2005 menjadi 5,71 juta jiwa pada tahun 2007 (Nainggolan 2008). Bila hal ini dibiarkan, maka akan berdampak pada menurunnya kualitas SDM dan ketahanan nasional.

Di sisi lain penduduk yang mengalami kekurangan pangan akan melakukan upaya yang sering disebut food coping strategy. Upaya yang dilakukan akan berbeda sesuai dengan norma dan tingkatan kemiskinan yang dialaminya (Maxwel et al., 1999). Diharapkan food coping strategy yang dilakukan dapat menurunkan intensitas kerawanan pangan dan dapat mencapai kecukupan gizi.

Tujuan penelitian ini adalah menganalisis determinan intensitas kerawanan pangan serta hubungannya dengan food coping strategies dan tingkat kecukupan energi, mencakup (1) sosial ekonomi dan intensitas kerawanan pangan keluarga; (2) food coping strategies dan tingkat kecukupan gizi; (3) hubungan intensitas kerawanan pangan dengan food coping strategies; (4) hubungan intensitas kerawanan pangan, food coping strategies dengan tingkat kecukupan energi; dan (5) determinan intensitas kerawanan pangan dan tingkat kecukupan energi.

\section{METODE}

Desain penelitian adalah Cross Sectional Study. Penelitian dilaksanakan dalam jangka waktu 9 bulan, mulai bulan April sampai de- 
ngan bulan Desember 2009, di Kabupaten Pandeglang, Propinsi Banten.

Dari Kabupaten Pandeglang dipilih dua kecamatan sebagai tempat penelitian yang mewakili kecamatan tahan pangan dan rawan pangan. Dari masing-masing kecamatan terpilih dipilih 2 desa representatif situasi ketahanan pangan tingkat kecamatan.

Sampel terdiri dari rumah tangga penerima program yang diambil secara purposif. Pemilihan secara purposif berdasarkan keterlibatan rumah tangga (8-10 rumah tangga per jenis program) pada program-program ketahanan pangan dan kemiskinan. Pada setiap desa diambil 55 rumahtangga, sehingga total sampel sebanyak 220 rumahtangga.

Data yang dikumpulkan merupakan data primer (karakteristik rumahtangga, intensitas kerawanan pangan, food coping strategy dan semi food frequency) dan data sekunder dari instansi terkait ketahanan pangan. Data diolah secara deskriptif dan inferensia. Sebelum dianalisis, data kualitatif diskor terlebih dahulu, dan dikategorikan berdasarkan interval jumlah kelas. Analisis korelasi digunakan untuk menganalisis hubungan antara karakteristik sosek dengan intensitas kerawanan pangan dan food coping strategy. Regresi linear berganda digunakan untuk menganalisis pengaruh karakteristik sosial ekonomi, intensitas kerawanan pangan dan food coping strategy terhadap tingkat kecukupan energi. Regresi Logistik (Hosmer \& Lemeshow, 1989) digunakan untuk menganalisis determinan intensitas kerawanan pangan dengan model:

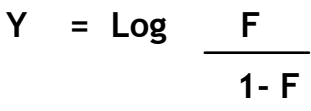

$=\beta_{0}+\beta_{1} \mathrm{PKP}+\beta_{2} \mathrm{FCS}+\beta_{3} \mathrm{PKK}+\beta_{4} \mathrm{JP}+\beta_{5} \mathrm{PJAR}+\varepsilon$

Keterangan :

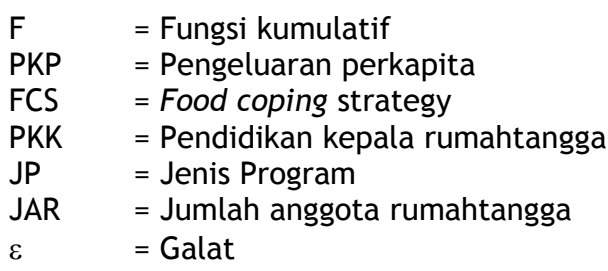

\section{HASIL DAN PEMBAHASAN}

Umur kepala keluarga berkisar antara 24 hingga 74 tahun dengan rataan $41.5 \pm 10.6$ dan bila dikelompokkan menurut kategori Papalia \& Olds (1981), sebagian besar kepala keluarga berada pada kelompok dewasa awal yaitu sebesar $50.7 \%$. Umur ibu berkisar antara 19 hingga 65 tahun dengan rataan $34 \pm 9.2$ dan bila dikelompokkan menurut kategori, sebagian besar ibu berada pada kelompok dewasa awal yaitu sebesar $84.1 \%$.

Lama pendidikan kepala keluarga berkisar antara 0 tahun hingga 12 tahun dengan rataan $5.5 \pm 2.5$. Lama pendidikan ibu berkisar antara 0 tahun hingga 12 tahun de-ngan rataan 5.0 \pm 2.9. Jika dikelompokkan ber-dasarkan tingkat pendidikan, maka sebagian besar kepala keluarga yaitu sebesar $85.1 \%$ mempunyai tingkat pendidikan setingkat SD. Begitu pula dengan tingkat pendidikan ibu, sebagian besar yaitu sebesar $72.5 \%$ mempunyai tingkat pendidikan setingkat SD.

Besar keluarga berkisar antara 2 hingga 11 orang dengan rataan $5.5 \pm 1.9$. Jika dikelompokkan berdasarkan kategori besar keluarga (BKKN, 1998), sebagian besar keluarga yaitu sebesar $57.1 \%$ termasuk kategori keluarga sedang.

Pengeluaran Rumah Tangga. Pengeluaran rumahtangga perbulan di kecamatan tahan pangan berkisar antara Rp 210 300,- dan Rp 2711 000,- dengan rataan Rp $1072358 \pm$ 506799 . Sedangkan pengeluaran di kecamatan rawan pangan berkisar antara Rp 90 000,- sampai Rp 3437 000,- dengan rataan Rp 1043153 \pm 495608 . Bila dilihat dari pengeluaran per kapita perbulan, maka rata-rata pengeluaran per kapita pada rumahtangga di kecamatan tahan pangan berkisar antara Rp 57 583,- hingga Rp 915 000,- dengan rata-rata Rp $205097 \pm 125$ 766. Sedangkan pengeluaran perkapita pada rumahtangga di kecamatan rawan pangan berkisar antara Rp 45 000,- hingga Rp 1145 667,dengan rata-rata Rp $262830 \pm 141$ 324. Berdasarkan uji $t$, terdapat perbedaan rata-rata pengeluaran perkapita di kecamatan tahan dan rawan pangan $(p=0.002)$. Bila pengeluaran per kapita contoh dibandingkan dengan Garis kemiskinan provinsi Banten tahun 2008 yaitu Rp 156 494, maka seperti terlihat pada Tabel 1 terdapat $28.6 \%$ rumahtangga contoh masuk dalam kategori miskin. Persentase kemiskinan ini diatas rata-rata persentase kemiskinan nasional 15.42 \% (TKPK 2009).

Pengeluaran Pangan dan Non Pangan. Rata-rata pengeluaran pangan perkapita per bulan pada rumahtangga di kecamatan tahan pangan adalah Rp 133 260. - dan rata-rata pengeluaran non pangan Rp 71836 atau masingmasing $64.97 \%$ dan $35.03 \%$ dari total pengeluaran. Pada rumahtangga di kecamatan rawan 
Tabel 1. Sebaran Rumahtangga menurut Kategori Kemiskinan

\begin{tabular}{lcccccc}
\hline \multirow{2}{*}{ Pengeluaran } & \multicolumn{2}{c}{ Kec Tahan Pangan } & \multicolumn{2}{c}{ Kec Rawan Pangan } & \multicolumn{2}{c}{ Total } \\
\cline { 2 - 7 } & $\mathrm{n}$ & $\%$ & $\mathrm{n}$ & $\%$ & $\mathrm{n}$ & $\%$ \\
\hline 1. Di bawah garis kemiskinan & 46 & 41.8 & 17 & 15.5 & 63 & 28.6 \\
2. Di atas garis kemiskinan & 64 & 58.2 & 93 & 84.5 & 157 & 71.4 \\
\hline \multicolumn{1}{c}{ Jumlah } & 110 & 100.0 & 110 & 100,0 & 220 & 100,0 \\
\hline
\end{tabular}

pangan rata-rata pengeluaran pangan dan non pangan perkapita adalah Rp 152662 dan Rp 110168 atau masing-masing 58.08\% dan 41.91\% dari total pengeluaran perkapita (Tabel 2). Rata-rata persentase pengeluaran pangan dan non pangan di dua kecamatan berbeda nyata $(p=0.001)$.

Tabel 2 menunjukkan bahwa secara proporsional pengeluaran pangan pada rumahtangga di kecamatan tahan pangan lebih besar dari proporsi pengeluaran pangan di kecamatan rawan pangan, dan berbeda nyata $(P=0.001)$. Hal ini disebabkan tingginya persentase rumahtangga miskin di kecamatan tahan pangan. Komposisi pengeluaran rumahtangga dapat dijadikan salah satu ukuran untuk menilai tingkat kesejahteraan, menurut den Hartog, van Staveren dan Broower, (1995), Behrman (1995), dan Smith (2003) pada keluarga berpendapatan tinggi, proporsi pengeluaran pangan tidak lebih dari $30 \%$ dari total pengeluaran, sedangkan pada rumahtangga miskin pengeluaran untuk pangan dapat mencapai lebih dari $70 \%$.

Lebih tingginya rumahtangga miskin di kecamatan tahan pangan dibanding di kecamatan rawan pangan, disebabkan karena rumahtangga di kecamatan rawan pangan selain mendapat BLT dan raskin juga banyak yang mendapat program berupa pemberian modal produktif, sedangkan pada rumahtangga di kecamatan tahan pangan lebih sedikit yang mendapat program modal produktif (Gambar 1).
Program peningkatan ketahanan pangan atau penanggulangan kemiskinan yang mempertimbangkan pendekatan keberlanjutan (Sustainable Livelihoods Approach) akan lebih efektif dalam mencapai ketahanan pangan dibanding program yang hanya bersifat pemberian (Farrington et.al. 1999).

Intensitas Kerawanan Pangan. Tingkat intensitas kerawanan pangan merupakan tingkat keseringan rumah tangga mengalami kerawanan pangan. Intensitas kerawanan pangan keluarga ditentukan berdasarkan persepsi responden terhadap seringnya terjadi kerawanan pangan (hampir setiap hari, hampir setiap minggu, hampir setiap bulan, beberapa kali dalam setahun atau tidak pernah) yang diukur dari beberapa indikator ketahanan pangan. Bila intensitas kerawanan pangan dikategorikan, maka seperti terlihat pada Tabel 3, tingkat intensitas kerawanan pangan sebagian besar keluarga berada pada kategori rendah yaitu sebesar $72.73 \%$. Lainnya yaitu sebesar $20 \%$ berada pada kategori sedang dan sebesar 7.27 $\%$ berada pada kategori tinggi.

Bila dilihat dari jenis kerawanan pangan yang dialaminya, maka dari Tabel 5 terlihat bahwa adanya kehawatiran terhadap persediaan makanan pokok habis dialami oleh sebagian besar rumahtangga (83.2\%), bahkan $46.5 \% \mathrm{di}$ antaranya mengalami kehawatiran ini setiap hari.

Tabel 2. Pengeluaran Rataan (Rp) Per Kapita Per Bulan Menurut Jenis Pengeluaran

\begin{tabular}{lccccccc}
\hline \multirow{2}{*}{$\begin{array}{c}\text { Jenis } \\
\text { Pengeluaran }\end{array}$} & \multicolumn{2}{c}{$\begin{array}{c}\text { Kecamatan } \\
\text { Tahan pangan }\end{array}$} & \multicolumn{2}{c}{$\begin{array}{c}\text { Kecamatan } \\
\text { Rawan Pangan }\end{array}$} & \multicolumn{2}{c}{ Total } & P \\
\cline { 2 - 9 } & \multicolumn{1}{c}{ Rp } & $\%$ & Rp & $\%$ & Rp & $\%$ & \\
\hline Pangan & 133260 & 64.97 & 152662 & 58.08 & 285922 & 61.10 & \\
Non Pangan & 71836 & 35.03 & 110168 & 41.91 & 182004 & 38.90 & $0.001^{* *}$ \\
Total & 205096 & 100.0 & 262830 & 100.0 & 467926 & 100.0 & \\
\hline
\end{tabular}


Tabel 3. Sebaran Responden Rumahtangga berdasarkan Program Pemerintah yang Didapatkan

\begin{tabular}{lccc}
\hline \multicolumn{1}{c}{ Program } & $\begin{array}{c}\text { Kecamatan Tahan } \\
\text { Pangan (\%) }\end{array}$ & $\begin{array}{c}\text { Kecamatan Rawan } \\
\text { Pangan (\%) }\end{array}$ & Total (\%) \\
\hline Program Kredit & 0 & 1.8 & 0.9 \\
Program Bantuan Teknologi & 0 & 0.9 & 0.5 \\
Program Bantuan Modal & 68.2 & 34.5 & 51.4 \\
Program PMT & 5.5 & 5.5 & 5.5 \\
Keluarga Harapan & 0 & 2.7 & 1.4 \\
BOS & 38.2 & 20 & 24.1 \\
Sembako Murah & 19.1 & 6.4 & 12.7 \\
Askeskin & 36.4 & 39.1 & 37.7 \\
Raskin & 85.5 & 78.2 & 81.8 \\
BLT & 50.9 & 65.5 & 58.2 \\
Program Lainnya & 1.8 & 32.7 & 17.3 \\
Tidak dapat program pemerintah & 0.9 & 1.8 & 1.4 \\
\hline
\end{tabular}

Tabel 4. Sebaran Rumahtangga menurut Tingkat Intensitas Kerawanan Pangan

\begin{tabular}{|c|c|c|c|c|c|c|c|}
\hline \multirow{2}{*}{$\begin{array}{c}\text { Intensitas } \\
\text { Kerawanan } \\
\text { Pangan }\end{array}$} & \multicolumn{2}{|c|}{$\begin{array}{c}\text { Kecamatan } \\
\text { Tahan pangan }\end{array}$} & \multicolumn{2}{|c|}{$\begin{array}{c}\text { Kecamatan } \\
\text { Rawan Pangan }\end{array}$} & \multicolumn{2}{|c|}{ Total } & \multirow[t]{2}{*}{$\mathrm{p}$} \\
\hline & $n$ & $\%$ & $n$ & $\%$ & $n$ & $\%$ & \\
\hline Rendah & 74 & 67.27 & 86 & 78.18 & 160 & 72.73 & \\
\hline $\begin{array}{l}\text { Sedang } \\
\text { Tinggi }\end{array}$ & $\begin{array}{l}24 \\
12\end{array}$ & $\begin{array}{l}21.82 \\
10.91\end{array}$ & $\begin{array}{c}20 \\
4\end{array}$ & $\begin{array}{c}18.18 \\
3.64\end{array}$ & $\begin{array}{l}44 \\
16\end{array}$ & $\begin{array}{c}20.00 \\
7.27\end{array}$ & 0.066 \\
\hline Total & 110 & 100 & 110 & 100 & 220 & 100 & \\
\hline
\end{tabular}

Kehawatiran akan persediaan makanan pokok, terlihat pula dari persepsi responden bahwa $25 \%$ responden dan $13,6 \%$ responden mengalami kekurangan persediaan makanan pokok yang dialaminya masing-masing setiap minggu dan setiap hari. Bahkan pada $0.5 \%$ rumahtangga contoh, intensitas kerawanan pangan sudah sangat tinggi sampai terjadi penurunan berat badan pada anak maupun anggota rumahtangga dewasa.

Ukuran keluarga atau banyaknya anggota keluarga akan mempengaruhi tingkat intensitas kerawanan pangan keluarga, terutama pada keluarga miskin. Hasil penelitian Kigutha (1994) dalam den Hartog, van Staveren dan Broower (1995) menunjukkan bahwa peningkatan jumlah anggota keluarga berhubungan negatif dengan konsumsi pangan hewani dan makanan pokok, yang mengakibatkan menurunnya konsumsi energi dan protein. Dari Tabel 6 terlihat bahwa pada ukuran keluarga kecil, sebagian besar berada pada intensitas kerawanan rendah, sebaliknya pada keluraga besar, sebagian besar berada pada intensitas kerawanan pangan tinggi. Berdasarkan uji korelasi pearson, terdapat hubungan positif $(r=$ $0.200)$ nyata $(p=0.003)$ antara besar keluarga dengan intensitas kerawanan pangan.

Tabel 6 juga menunjukkan hubungan tingkat kemiskinan dengan intensitas kerawanan pangan. Tampak bahwa proporsi terbesar keluarga miskin berada pada kondisi intensitas kerawanan pangan tinggi (50\%) dan sedang (38.6\%). Sedangkan keluarga tidak miskin proporsi terbesar berada pada kondisi intensitas kerawanan pangan rendah $(76.30 \%)$. Hasil uji korelasi pearson menunjukkan adanya hubungan yang nyata $(\mathrm{p}=0.000)$ negatif $(\mathrm{r}=-0.285)$ antara tingkat kemiskinan dengan intensitas kerawanan pangan. Andrews et al. (2000) dalam Kennedy (2003) menunjukkan bahwa terdapat hubungan antara ketidaktahanan pangan dengan pendapatan. Kejadian ketidaktahanan pangan 12 kali lebih besar pada rumahtangga yang berada dibawah garis kemiskinan dibanding dengan rumahtangga dengan pendapatan 1.85 kali lebih besar dari garis kemiskinan. 
Tabel 5. Persentase Rumahtangga berdasarkan Intensitas Kerawanan Pangan yang Dialaminya

\begin{tabular}{|c|c|c|c|c|c|}
\hline Jenis Kerawanan Pangan & $\begin{array}{l}\text { Hampir } \\
\text { setiap } \\
\text { hari }\end{array}$ & $\begin{array}{l}\text { Hampir } \\
\text { setiap } \\
\text { minggu }\end{array}$ & $\begin{array}{l}\text { Hampir } \\
\text { setiap } \\
\text { bulan }\end{array}$ & $\begin{array}{l}\text { Beberapa } \\
\text { kali dlm } \\
\text { setahun }\end{array}$ & $\begin{array}{l}\text { Tidak } \\
\text { pernah }\end{array}$ \\
\hline $\begin{array}{l}\text { Khawatir persediaan makanan pokok di } \\
\text { rumah habis }\end{array}$ & 46.5 & 15.9 & 8.6 & 12.3 & 16.8 \\
\hline $\begin{array}{l}\text { Persediaan makanan pokok sedikit dan } \\
\text { tidak punya uang untuk membeli }\end{array}$ & 13.6 & 25.0 & 16.8 & 13.6 & 30.9 \\
\hline $\begin{array}{l}\text { Tidak dapat menyediakan makanan } \\
\text { bergizi seimbang (empat sehat) untuk } \\
\text { rumahtangga }\end{array}$ & 15.5 & 11.4 & 7.3 & 4.1 & 61.8 \\
\hline $\begin{array}{l}\text { Tidak dapat menyediakan makanan } \\
\text { bergizi seimbang (empat sehat) untuk } \\
\text { anak }\end{array}$ & 14.5 & 10.5 & 6.4 & 2.7 & 65.9 \\
\hline $\begin{array}{l}\text { Anak-anak tidak memperoleh makanan } \\
\text { yang cukup }\end{array}$ & 6.4 & 10.5 & 4.5 & 3.6 & 75.0 \\
\hline $\begin{array}{l}\text { Merasa sangat lapar dan tidak ada } \\
\text { makanan di rumah }\end{array}$ & 3.2 & 13.2 & 5.0 & 5.0 & 73.6 \\
\hline $\begin{array}{l}\text { Ada anggota keluarga selain anak yang } \\
\text { mengurangi makan karena tidak cukup } \\
\text { makanan }\end{array}$ & 1.8 & 5.0 & 3.6 & 3.6 & 85.9 \\
\hline $\begin{array}{l}\text { Mengurangi porsi makan untuk anak } \\
\text { karena tidak cukup makanan }\end{array}$ & 2.3 & 8.2 & 5.9 & 4.5 & 79.1 \\
\hline $\begin{array}{l}\text { Ada anggota keluarga selain anak tidak } \\
\text { makan seharian karena tidak punya } \\
\text { uang }\end{array}$ & 0.9 & 1.4 & 3.6 & 3.2 & 90.9 \\
\hline $\begin{array}{l}\text { Ada anak tidak makan karena tidak } \\
\text { punya uang }\end{array}$ & 0.9 & 2.7 & 2.3 & 2.7 & 91.4 \\
\hline $\begin{array}{l}\text { Ada anak yang mengalami penurunan } \\
\text { berat badan karena kurang makan atau } \\
\text { tidak mampu membeli makanan }\end{array}$ & 0.5 & 0.9 & 4.5 & 4,5 & 89.5 \\
\hline $\begin{array}{l}\text { Ada anggota keluarga dewasa } \\
\text { mengalami penurunan berat badan } \\
\text { karena kurang makan atau tidak mampu } \\
\text { membeli makanan }\end{array}$ & 0.5 & 0.9 & 3.2 & 3.6 & 91.8 \\
\hline
\end{tabular}

Tabel 6. Besar Keluarga dan Pengeluaran dengan Tingkat Intensitas Kerawanan Pangan

\begin{tabular}{|c|c|c|c|c|c|c|c|}
\hline \multirow{3}{*}{ Karakteristik } & \multicolumn{6}{|c|}{ Tingkat intensitas kerawanan pangan } & \multirow{3}{*}{ Peluang } \\
\hline & \multicolumn{2}{|c|}{ Rendah } & \multicolumn{2}{|c|}{ Sedang } & \multicolumn{2}{|c|}{ Tinggi } & \\
\hline & $\mathrm{n}$ & $\%$ & $\mathrm{n}$ & $\%$ & $\mathrm{n}$ & $\%$ & \\
\hline \multicolumn{8}{|l|}{ Besar keluarga } \\
\hline Kecil $(\leq 4)$ & 78 & 48.8 & 14 & 31.8 & 4 & 25 & $P=0.003$ \\
\hline Sedang (5-7) & 66 & 41.3 & 25 & 56.8 & 7 & 43.8 & $r=0.200$ \\
\hline Besar $(\geq 8)$ & 16 & 10 & 5 & 11.4 & 5 & 31.3 & \\
\hline Total & 160 & 100 & 44 & 100 & 16 & 100 & \\
\hline \multicolumn{8}{|l|}{ Tingkat Kemiskinan } \\
\hline Miskin (<156 494) & 38 & 23.80 & 17 & 38.60 & 8 & 50.00 & $r=-0.285^{*}$ \\
\hline Tidak miskin $(>156494)$ & 122 & 76.30 & 27 & 61.40 & 8 & 50.00 & $p=0.000$ \\
\hline Total & 160 & 100 & 44 & 100 & 16 & 100 & \\
\hline
\end{tabular}

Food Coping strategy. Food Coping strategy merupakan upaya yang dilakukan seseorang dalam mengatasi keadaan yang tidak menguntungkan termasuk pada saat menurunnya akses terhadap pangan (Maxwell et al., 1999). Dari hasil penelitian diperoleh bahwa sebagian besar keluarga yaitu sebesar $75.7 \%$ melakukan food coping strategy berupa meminjam uang pada orang lain (rentenir, hutang di warung, dll), selanjutnya yaitu sebesar $58.6 \%$ melakukan coping strategy berupa meminjam uang pada saudara/kerabat dan sebesar $40.0 \%$ melakukan coping strategy berupa mengurangi jumlah pangan yang dimakan 
(Tabel 7). Menurut Corbett (1998) dalam Anonymous (2003a), bentuk-bentuk strategi food coping yang berbeda didasarkan pada berbagai kondisi dan tingkat kemiskinan yang berbeda.

Bila dikategorikan menurut tingkatan food coping strategy yang dilakukan, sebagian besar keluarga yaitu sebesar $81.82 \%$ berada pada kategori rendah, lainnya yaitu sebesar $15.91 \%$ berada pada kategori sedang dan $2.27 \%$ berada pada kategori tinggi (Tabel 8).

Bila tindakan coping ini dihubungkan dengan intensitas kerawanan pangan, maka seperti terlihat pada Tabel 8 bahwa sebagian besar rumahtangga $(77.78 \%)$ melakukan coping strategi pada tingkatan rendah saat intensitas kerawanan pangan rendah dan sebaliknya sebagian besar rumahtangga dengan tingkat food coping strategi tinggi pada saat intensitas kerawanan tinggi. Berdasarkan uji korelasi pearson terdapat hubungan positif $(r=0.483)$ nyata $(\mathrm{p}=0.000)$ antara intensitas kerawanan pangan dan food coping strategi. Menurut Maxwell at al (1999) food coping strategy dapat dijadikan indikator kerawanan pangan, semakin tinggi ting tingkat food coping strategy, maka semakin tinggi tingkat kerawanan pangannya.

Konsumsi pangan. Kebiasaan konsumsi pangan rumahtangga dapat dilihat dari frekuensi dan berat pangan yang dikonsumsi yang dikelompokkan dalam enam kelompok pangan. Dari Tabel 10 terlihat bahwa frekuensi konsumsi nasi 13 kali perminggu, artinya rumah tangga contoh makan rata-rata 1-2 kali dalam satu hari. Keadaan ini tidak mengherankan karena konsumsi mi frekuensinya 7.8 kali per minggu, artinya rumahtangga contoh mengonsumsi mie minimal satu kali dalam sehari, dan ini dimungkinkan sebagai substitusi konsumsi nasi. Pada umumnya mereka setiap hari mengonsumsi pangan hewani, kacang-kacangan, sayuran dan buah. Jenis pangan hewani yang sering di konsumsi adalah ikan asin, susu dan

Tabel 7. Sebaran Rumahtangga menurut Jenis Coping Strategy yang Dilakukan

\begin{tabular}{clrr}
\hline No. & \multicolumn{1}{c}{ Coping Strategy } & $\mathbf{n}$ & $\%$ \\
\hline 1. & Mengalihkan pangan pokok utama ke jenis lain yang lebih murah & 28 & 12.9 \\
2. & Mengurangi jumlah pangan yang dimakan & 88 & 40.0 \\
3. & Mengurangi frekuensi makan per hari & 60 & 27.1 \\
4. & Meminta bantuan pangan & 47 & 21.4 \\
5. & Meminjam uang pada saudara/kerabat & 129 & 58.6 \\
6. & Meminjam uang pada orang lain (rentenir, hutang di warung, dll) & 167 & 75.7 \\
7. & Menjual aset non produktif & 28 & 12.9 \\
8. & Tidak membayar biaya/uang sekolah anak & 6 & 2.9 \\
9. & Laki-laki mencari pekerjaan di kota/tempat lain (ke luar desa/kota) & 16 & 7.1 \\
10. & Menjual aset produktif (tanah,alat pertanian, ternak, dll) & 13 & 5.7 \\
11. & Menghentikan pendidikan/sekolah anak & 16 & 7.1 \\
\hline
\end{tabular}

Tabel 8. Sebaran Keluarga Menurut Tingkat Food Coping Strategy yang Dilakukan

\begin{tabular}{|c|c|c|c|c|c|c|c|}
\hline \multirow{2}{*}{$\begin{array}{l}\text { Tingkat Food } \\
\text { Coping Startegy }\end{array}$} & \multicolumn{2}{|c|}{$\begin{array}{c}\text { Kecamatan } \\
\text { Tahan pangan }\end{array}$} & \multicolumn{2}{|c|}{$\begin{array}{c}\text { Kecamatan } \\
\text { Rawan Pangan }\end{array}$} & \multicolumn{2}{|c|}{ Total } & \multirow[t]{2}{*}{ P } \\
\hline & $\mathrm{n}$ & $\%$ & $\mathbf{N}$ & $\%$ & $n$ & $\%$ & \\
\hline Rendah & 88 & 80.00 & 92 & 83.64 & 180 & 81.82 & \\
\hline Sedang & 19 & 17.27 & 16 & 14.55 & 35 & 15.91 & $0.009^{* *}$ \\
\hline Tinggi & 3 & 2.73 & 2 & 1.82 & 5 & 2.27 & \\
\hline Total & 110 & 100 & 110 & 100 & 220 & 100 & \\
\hline
\end{tabular}

Tabel 9. Hubungan Intensitas Kerawanan Pangan dan Tingkat Food Coping Strategy

\begin{tabular}{|c|c|c|c|c|c|c|c|c|c|}
\hline \multirow{3}{*}{$\begin{array}{l}\text { Intensitas } \\
\text { Kerawanan } \\
\text { Pangan }\end{array}$} & \multicolumn{6}{|c|}{ Tingkat Food Coping Strategy } & \multirow{2}{*}{\multicolumn{2}{|c|}{ Total }} & \multirow{3}{*}{$\mathbf{p}$} \\
\hline & \multicolumn{2}{|c|}{ Rendah } & \multicolumn{2}{|c|}{ Sedang } & \multicolumn{2}{|c|}{ Tinggi } & & & \\
\hline & $\mathrm{n}$ & $\%$ & $n$ & $\%$ & $n$ & $\%$ & $\mathrm{n}$ & $\%$ & \\
\hline Rendah & 140 & 77.78 & 19 & 54.29 & 1 & 20.00 & 160 & 72.73 & \multirow{4}{*}{$0.000^{* *}$} \\
\hline Sedang & 33 & 18.33 & 10 & 28.57 & 1 & 20.00 & 44 & 20.00 & \\
\hline Tinggi & 7 & 3.89 & 6 & 17.14 & 3 & 60.00 & 16 & 7.27 & \\
\hline Total & 180 & 100 & 35 & 100 & 5 & 100 & 220 & 100 & \\
\hline
\end{tabular}


Tabel 10. Rataan Frekuensi Konsumsi Pangan (Kali/Minggu) pada Kelompok Tahan Pangan dan Rawan Pangan

\begin{tabular}{|c|c|c|c|c|}
\hline \multirow[t]{2}{*}{ Kelompok Pangan } & $\begin{array}{c}\text { Kecamatan Tahan } \\
\text { Pangan } \\
(\mathrm{n}=110) \\
\end{array}$ & $\begin{array}{c}\text { Kecamatan Rawan } \\
\text { Pangan } \\
(\mathrm{n}=110) \\
\end{array}$ & $\begin{array}{c}\text { Total } \\
(n=220)\end{array}$ & \multirow[t]{2}{*}{ Peluang } \\
\hline & Rataan \pm Sd & Rataan \pm Sd & Rataan \pm Sd & \\
\hline $\begin{array}{l}\text { Padi-padian } \\
\text { - Nasi } \\
\text { - Mie } \\
\text { - Roti }\end{array}$ & $\begin{array}{l}11.8 \pm 7.1 \\
8.0 \pm 7.1 \\
6.9 \pm 6.3\end{array}$ & $\begin{array}{l}14.2 \pm 8.4 \\
7.7 \pm 8.0 \\
7.0 \pm 7.7\end{array}$ & $\begin{array}{l}13.0 \pm 3.5 \\
7.8 \pm 5.6 \\
7.0 \pm 6.2\end{array}$ & $\begin{array}{l}0.000^{* *} \\
0.406 \\
0.528\end{array}$ \\
\hline $\begin{array}{l}\text { Pangan Hewani } \\
\text { - Daging Ayam } \\
\text { - Telur } \\
\text { - Ikan Asin } \\
\text { - Ikan Segar } \\
\text { - Susu }\end{array}$ & $\begin{array}{c}8.5 \pm 7.2 \\
8.2 \pm 7.1 \\
10.5 \pm 6.7 \\
8.9 \pm 6.9 \\
12.5 \pm 8.1\end{array}$ & $\begin{array}{c}9.3 \pm 8.5 \\
8.8 \pm 7.2 \\
12.8 \pm 8.1 \\
10.2 \pm 7.9 \\
7.9 \pm 6.5\end{array}$ & $\begin{array}{c}8.9 \pm 6.5 \\
8.5 \pm 5.5 \\
11.6 \pm 6.6 \\
9.6 \pm 6.5 \\
10.2 \pm 8.8\end{array}$ & $\begin{array}{l}0.228 \\
0.606 \\
0.069 \\
0.000^{* *} \\
0.005^{* *}\end{array}$ \\
\hline $\begin{array}{l}\text { Kacang-kacangan } \\
\text { - Tempe } \\
\text { - Tahu }\end{array}$ & $\begin{array}{c}9.7 \pm 7.7 \\
10.2 \pm 6.9\end{array}$ & $\begin{array}{c}9 \pm 8.3 \\
10.5 \pm 9.4\end{array}$ & $\begin{array}{c}9.4 \pm 7.4 \\
10.4 \pm 7.0\end{array}$ & $\begin{array}{l}0.065 \\
0.582\end{array}$ \\
\hline Sayuran & $9.7 \pm 7.6$ & $10.7 \pm 8.3$ & $15.1 \pm 7.0$ & 0.060 \\
\hline $\begin{array}{l}\text { Buah-buahan } \\
\text { - Jeruk }\end{array}$ & $8.7 \pm 8.0$ & $9.2 \pm 10.9$ & $9 \pm 12$ & 0.273 \\
\hline $\begin{array}{l}\text { Lain-lain } \\
\text { - Teh } \\
\text { - Kopi } \\
\text { - Gorengan }\end{array}$ & $\begin{array}{l}9.5 \pm 7.4 \\
16 \pm 32.0 \\
9.6 \pm 7.5\end{array}$ & $\begin{array}{c}10.6 \pm 7.0 \\
15.7 \pm 10.5 \\
8.6 \pm 6.7\end{array}$ & $\begin{array}{l}10.1 \pm 7.1 \\
15.9 \pm 20 \\
9.1 \pm 6.8\end{array}$ & $\begin{array}{l}0.965 \\
0.201 \\
0.034^{*}\end{array}$ \\
\hline
\end{tabular}

Keterangan: ${ }^{* *}=$ sangat nyata pada taraf 0.01

*= nyata pada taraf 0.05

Tabel 11. Rataan Berat Pangan (gram) Per Hari pada Kelompok Tahan Pangan dan Rawan Pangan

\begin{tabular}{|c|c|c|c|}
\hline Kelompok Pangan & $\begin{array}{c}\text { Kecamatan Tahan } \\
\text { Pangan } \\
(\mathrm{n}=110)\end{array}$ & $\begin{array}{c}\text { Kecamatan Rawan } \\
\text { Pangan } \\
(\mathrm{n}=110)\end{array}$ & $\begin{array}{c}\text { Total } \\
(n=220)\end{array}$ \\
\hline & Rataan \pm Sd & Rataan \pm Sd & Rataan \pm Sd \\
\hline $\begin{array}{l}\text { Padi-padian } \\
\text { - Beras } \\
\text { - Mie } \\
\text { - Roti }\end{array}$ & $\begin{array}{l}582 \pm 65.5 \\
72.6 \pm 36.1 \\
38.3 \pm 17.8\end{array}$ & $\begin{aligned} 570.3 & \pm 80.14 \\
89.9 & \pm 47.4 \\
23.2 & \pm 17.4\end{aligned}$ & $\begin{array}{l}576 \pm 73.28 \\
80.3 \pm 42.3 \\
29.5 \pm 19.0\end{array}$ \\
\hline $\begin{array}{l}\text { Pangan hewani } \\
\text {-Daging Ayam } \\
\text { - Telur } \\
\text { - Ikan Asin } \\
\text { - Ikan Segar } \\
\text { - Susu }\end{array}$ & $\begin{array}{c}35.7 \pm 13.9 \\
33.9 \pm 22.4 \\
33.1 \pm 10.3 \\
40.9 \pm 13 \\
58.5 \pm 35.9\end{array}$ & $\begin{array}{c}45.5 \pm 43.9 \\
43.8 \pm 14 \\
16.8 \pm 10.3 \\
53.7 \pm 25.4 \\
91.6 \pm 61.6\end{array}$ & $\begin{array}{l}40.6 \pm 37.2 \\
36.8 \pm 20.7 \\
24.8 \pm 13.2 \\
49.3 \pm 22.7 \\
78.2 \pm 54.7\end{array}$ \\
\hline $\begin{array}{l}\text { Kacang-kacangan } \\
\text { - Tempe } \\
\text { - Tahu }\end{array}$ & $\begin{array}{l}35.9 \pm 13.4 \\
69.9 \pm 28.1\end{array}$ & $\begin{array}{l}37.4 \pm 17.8 \\
72.7 \pm 31.6\end{array}$ & $\begin{array}{l}36.7 \pm 15.8 \\
71.4 \pm 30.0\end{array}$ \\
\hline $\begin{array}{l}\text { Sayuran } \\
\text { - Sayur asem } \\
\text { - Sayur sop }\end{array}$ & $\begin{array}{l}97.7 \pm 69.9 \\
90.1 \pm 60.6\end{array}$ & $\begin{array}{c}136.9 \pm 78.6 \\
145 \pm 60.4\end{array}$ & $\begin{array}{l}115.9 \pm 76.4 \\
135.5 \pm 63.7\end{array}$ \\
\hline $\begin{array}{l}\text { Buah-buahan } \\
\text { - Jeruk }\end{array}$ & $66.7 \pm 23.6$ & $8.70 \pm 17.565$ & $42.0 \pm 45.9$ \\
\hline $\begin{array}{l}\text { Lain-lain } \\
\text { - Teh } \\
\text { - Kopi } \\
\text { - Gorengan }\end{array}$ & $\begin{array}{c}4.5 \pm 5.5 \\
2.2 \pm 1.7 \\
18.9 \pm 30.7\end{array}$ & $\begin{array}{l}4.8 \pm 3.14 \\
3.53 \pm 1.53 \\
50.6 \pm 67.9\end{array}$ & $\begin{array}{c}4.7 \pm 4.3 \\
2.9 \pm 1.7 \\
42.2 \pm 61.5\end{array}$ \\
\hline
\end{tabular}


ikan segar. Terdapat perbedaan nyata ratarata frekuensi konsumsi nasi $(p=0.000)$, ikan segar $(p=0.000)$, susu $(p=0.005)$ dan gorengan $(p=0.34)$ pada rumahtangga di kecamatan tahan dan rawan pangan.

Bila dilihat dari berat pangan yang dikonsumsi, maka dari Tabel 11 terlihat bahwa rataan konsumsi kelompok padi-padian per kapita perhari terutama beras adalah 376 gr per kapita perhari. Tingginya berat beras yang dikonsumsi menunjukkan pada tingginya kontribusi sumber karbohidrat terhadap pemenuhan energi, dan ini terlihat dari tingginya nilai SSR (71.3) artinya $71.3 \%$ energi berasal dari sumber karbohidrat (Tabel 12).

\section{Tingkat kecukupan Zat Gizi}

Tingkat kecukupan energi dan protein sebesar masing-masing $101.5 \%$ dan $92.3 \%$, artinya tingkat kecukupan energi dan protein contoh telah memenuhi kkecukupan energi yang dianjurkan (>90\% RDA) (Tabel 7). Sedangkan tingkat kecukupan untuk kalsium, vitamin A dan C masih dibawah RDA (Tabel 12). Tingkat kecupupan energi dan protein contoh di kecamatan tahan pangan lebih kecil dibanding di kecamatan rawan pangan, dengan perbedaan yang nyata $(p=0.000)$.

Bila tingkat kecukupan energi (TKE) dan protein (TKP) dikategorikan menjadi defisit (< $90 \%$ RDA) dan cukup ( $\geq 90 \%$ RDA), serta dihubungkan dengan intensitas kerawanan pangan, maka terlihat dari Tabel 13. Sebagian besar contoh $(66.25 \%$ dan $51.25 \%)$ dengan tingkat intensitas kerawanan pangan rendah mempunyai TKE dan TKP $\geq 90 \%$ RDA, sebaliknya contoh dengan intensitas kerawanan pangan tinggi sebagian besar $(62.5 \%$ dan 87.5\%) mempunyai TKE dan TKP $<90 \%$ RDA.

Tabel 12. Rataan dan Simpangan Baku Tingkat Kecukupan Gizi dan SSR Individu Lapar dan Tidak Lapar

\begin{tabular}{|c|c|c|c|c|}
\hline \multirow{2}{*}{ Karakteristik } & $\begin{array}{l}\text { Kec Tahan Pangan } \\
(n=110)\end{array}$ & $\begin{array}{c}\text { Kec Rawan Pangan } \\
(n=110)\end{array}$ & $\begin{array}{c}\text { Total } \\
(\mathrm{n}=220) \\
\end{array}$ & \multirow{2}{*}{ Peluang } \\
\hline & $\begin{array}{l}\text { Rataan } \pm \text { Sd } \\
\text { (min; maks) }\end{array}$ & $\begin{array}{l}\text { Rataan } \pm \text { Sd } \\
\text { (min; maks) }\end{array}$ & $\begin{array}{l}\text { Rataan } \pm \text { Sd } \\
\text { (min; maks) }\end{array}$ & \\
\hline Energi & $\begin{array}{l}97.8 \pm 25.4 \\
61.5 ; 142.2\end{array}$ & $\begin{array}{l}105.3 \pm 23.4 \\
61.2 ; 140.9\end{array}$ & $\begin{array}{l}101.5 \pm 24.6 \\
61.2 ; 142.2\end{array}$ & $0.000^{*}$ \\
\hline Protein & $\begin{array}{l}86.9 \pm 22.8 \\
60.1 ; 140.2\end{array}$ & $\begin{array}{l}97.7 \pm 25.8 \\
60.4 ; 140.4\end{array}$ & $\begin{array}{l}92.3 \pm 24.9 \\
60.1 ; 140.4\end{array}$ & $0.000^{*}$ \\
\hline Kalsium & $\begin{array}{c}22.0 \pm 24.6 \\
2.2 ; 133.9\end{array}$ & $\begin{array}{l}34.6 \pm 34.4 \\
3.9 ; 295.6\end{array}$ & $\begin{array}{l}28.3 \pm 30.5 \\
2.2 ; 295.6\end{array}$ & 0.113 \\
\hline Phospor & $\begin{array}{l}86.4 \pm 67.5 \\
10.7 ; 309.4\end{array}$ & $\begin{array}{l}123.4 \pm 68.3 \\
28.4 ; 212.3\end{array}$ & $\begin{array}{l}104.9 \pm 70.2 \\
10.7 ; 309.3\end{array}$ & 0.023 \\
\hline Zat Besi & $\begin{array}{c}104.6 \pm 86.7 \\
9.6 ; 207.6\end{array}$ & $\begin{array}{l}108.0 \pm 52.0 \\
29.3 ; 198.0\end{array}$ & $\begin{array}{c}106.3 \pm 71.4 \\
9.6 ; 207.6\end{array}$ & 0.251 \\
\hline Vit. A & $\begin{array}{l}23.4 \pm 35.7 \\
0.0 ; 149.0\end{array}$ & $\begin{array}{l}56.8 \pm 54.0 \\
0.0 ; 249.8\end{array}$ & $\begin{array}{l}40.1 \pm 48.7 \\
0.0 ; 249.8\end{array}$ & $0.008^{*}$ \\
\hline Vit. C & $\begin{array}{l}15.7 \pm 51.2 \\
0.0 ; 315.8\end{array}$ & $\begin{array}{l}26.7 \pm 37.1 \\
0.0 ; 227.3\end{array}$ & $\begin{array}{l}21.2 \pm 44.9 \\
0.0 ; 315.8\end{array}$ & 0.269 \\
\hline SSR & $70.4 \pm 5.04$ & $72.1 \pm 2.3$ & $71.3 \pm 7.34$ & \\
\hline
\end{tabular}

Keterangan: * = sangat nyata pada taraf 0.01

Tabel 13. Hubungan Intensitas Kerawanan Pangan dan Tingkat Kecukupan Energi dan Protein

\begin{tabular}{|c|c|c|c|c|c|c|c|c|c|}
\hline \multirow{3}{*}{$\begin{array}{l}\text { Tingkat } \\
\text { Kecukupan } \\
\text { Gizi }\end{array}$} & \multicolumn{6}{|c|}{ Intensitas Kerawanan Pangan } & \multirow{2}{*}{\multicolumn{2}{|c|}{ Total }} & \multirow{3}{*}{$\mathrm{p}$} \\
\hline & \multicolumn{2}{|c|}{ Rendah } & \multicolumn{2}{|c|}{ Sedang } & \multicolumn{2}{|c|}{ Tinggi } & & & \\
\hline & $\mathrm{n}$ & $\%$ & $\mathrm{n}$ & $\%$ & $\mathrm{n}$ & $\%$ & $\mathrm{n}$ & $\%$ & \\
\hline \multicolumn{10}{|c|}{ Energi } \\
\hline Defisit & 54 & 33.75 & 26 & 59.09 & 10 & 62.50 & 90 & 40.91 & \\
\hline Cukup & 106 & 66.25 & 18 & 40.91 & 6 & 37.50 & 130 & 59.09 & $0.000^{* *}$ \\
\hline Total & 160 & 100 & 44 & 100 & 16 & 100 & 220 & 100 & \\
\hline \multicolumn{10}{|c|}{ Protein } \\
\hline Defisit & 78 & 48.75 & 35 & 79.55 & 14 & 87.50 & 127 & 57.73 & \\
\hline Cukup & 82 & 51.25 & 9 & 20.45 & 2 & 12.50 & 93 & 42.27 & $0.000^{* *}$ \\
\hline Total & 160 & 100 & 44 & 100 & 16 & 100 & 220 & 100 & \\
\hline
\end{tabular}


Berdasar uji korelasi pearson menunjukkan hubungan nyata $(p=0.000)$ negatif antara intensitas kerawanan pangan dengan TKE $(r=-0.303)$ dan TKP $(r=-0.363)$.

\section{Determinan Intensitas Kerawanan Pangan}

Determinan intensitas kerawanan pangan dianalisis dengan menggunakan regresi logistik, dengan peubah dikotomi yaitu intensitas kerawanan pangan rendah $=0$ dan tinggi $=$ 1. Sebagai peubah bebas adalah peubah yang mempunyai korelasi dengan intensitas kerawanan pangan yaitu pengeluaran per kapita, umur KK, jumlah anggota keluarga dan food coping strategi dan dibuat dalam bentuk kategori (Rose, 1999).

Hasil analisa menunjukkan pengeluaran perkapita dengan kategori di bawah dan di atas garis kemiskinan (PKP) serta adanya perhatian pemerintah (PP) dengan diberi dan tidak diberi program peningkatan ketahanan pangan yang berpengaruh terhadap kejadian intensitas kerawanan pangan yaitu dengan odds ratio $=4.033 \mathrm{PKP}$ dan 6.664 $\mathrm{PP}$, artinya rumahtangga yang hidup di atas garis kemis kinan juga rumahtangga yang menerima program ketahanan pangan berupa modal usaha mempunyai peluang intensitas kerawanan pangan rendah sebesar 4.033 kali dan 6.664 kali dibanding rumahtangga yang hidup dibawah garis kemiskinan dan yang mendapat program ketahanan pangan berupa pemberian saja (raskin) dengan $\mathrm{R}^{2}=0.367$. Hal ini sesuai dengan FAO (1997), bahwa determinan utama dari ketahanan pangan/ketidaktahanan pangan adalah pendapatan yang memadai atau daya beli untuk memenuhi biaya hidup.

Adapun model logistiknya adalah:

$$
\begin{aligned}
\log & \frac{F}{1-F} \\
= & -3.673+1.395 \text { PKP + 1.897 JP }
\end{aligned}
$$

Keterangan:

PKP = Pengeluaran perkapita

$\mathrm{JP}=$ Jenis program ketahanan pangan yang diterima

\section{Determinan Tingkat Kecukupan Energi (TKE)}

Faktor yang diduga berpengaruh terhadap TKE dan TKP adalah faktor sosial ekonomi (umur KK, Jumlah anggota rumahtangga dan pengeluaran per kapita), intensitas kerawanan pangan dan food coping strategi. Hasil analisis regresi linear berganda menunjukkan faktor yang berpengaruh nyata terhadap TKE adalah pengeluaran perkapita, intensitas kerawanan pangan dan jumlah anggota rumahtangga. Se- dangkan coping stategy dan jenis program yang diterima tidak menunjukkan adanya pengaruh yang nyata terhadap tingkat kecukupan energi. Adapun model regresinya sebagai berikut:

TKE $=86.172+1.303$ PKP -0.352 IKP -1.128 JAR

Keterangan:

PKP = pengeluaran perkapita

IKP = intensitas Kerawanan pangan

JAR = jumlah anggota rumahtangga

\section{KESIMPULAN}

Tingkat pendidikan kepala keluarga maupun ibu sebagian besar $85.1 \%$ dan $72.5 \%$ hanya sampai SD. Besar keluarga sebagian besar $57.1 \%$ termasuk kategori keluarga sedang (5-7 orang). Sebesar $28.6 \%$ rumahtangga contoh masuk ke dalam kategori miskin. Dengan rata-rata proporsi pengeluaran untuk pangan $61.10 \%$ dari total pengeluaran.

Tingkat intensitas kerawanan pangan sebagian besar keluarga (72.73 \%) berada pada kategori rendah, dengan jenis kerawanan terbanyak pada sedikitnya persediaan pangan. Tingkat intensitas kerawanan pangan kategori rendah pada kecamatan tahan dan rawan pangan masing-masing $67.27 \%$ dan $78.18 \%$. Sebesar $7.27 \%$ contoh berada pada kategori intensitas kerawanan pangan tinggi, sampai mengurangi porsi makan anak hampir setiap minggu. Intensitas kerawanan pangan berhubungan negatif nyata dengan pengeluaran per kapita.

Food Coping strategy yang dilakukan oleh anggota rumah tangga sebagian $81.82 \%$ masih dalam kategori rendah dengan upaya yang dilakukan berupa meminjam uang baik pada saudara atau rentenir, serta melakukan pengurangan jumlah pangan yang dikonsumsi. Di kecamatan rawan proporsi contoh dengan kategori food coping startegi rendah lebih tinggi (83.64\%) dibanding di kecamatan tahan pangan (80\%). Food coping startegy berhubungan positif dengan intensitas kerawanan pangan.

Rata-rata tingkat kecukupan energi (TKE) dan protein (TKP) sebesar masing-masing 101,5\% dan 92.3\%. Di kecamatan tahan pangan rata-rata TKE dan TKP masing-masing sebesar 97.8\% dan $86.9 \%$ lebih rendah dibandingkan di Kecamatan rawan pangan yaitu masing-masing $105.3 \%$ dan $97.7 \%$, dan perbedaan ini nyata $(p=$ 0.00). TKE dan TKP berhubungan negatif dengan intensitas kerawanan pangan. 
Determinan intensitas kerawanan pangan adalah pengeluaran per kaipta (OR= 4.033) dan jenis program yang diterima $(O R=$ 6.664). Faktor yang berpengaruh terhadap TKE adalah intensitas kerawanan pangan, pengeluaran per kapita dan jumlah anggota rumahtangga.

\section{DAFTAR PUSTAKA}

Anonymous. 2003. Coping strategis. www. tulane.edu/panda2/fs/copingstrategy/n ewpage4.htm/introduction. [20 Januari 2008].

Berhman JR. 1995. Household Behaviour, Preschool Child Health and Nutrition, and the Role of Information. Cornell University Press, Ithaca and London.

Den Hartog, Van Staveren AP, Wija A dan Broower ID. 1995. Manual for Social Surveys on Food Habits and Consumption individu Developing Countries. Margraf Verlag, weikersheim, Germani.

[FAO] Food and Agriculture Organisation. 1997. Report of the World Food Summit, Rome.13-17 November 1996 (Part One).

FAO. 2003. Proceedings, Measurement and Assessment of Food Devrivation and Undernutrition. Internastional Scientific Symposium. Rome, 26-28 Juni 2002.

Farrington J et.al. 1999. Sustainable Livelihoods in Practice : Early Applications of Concepts in Rural Areas. ODI Natural Resources Perspectives. Overseas Development Institute, London.
Hosmer DW and Lemesshow S. 1989. Applied Logistic Regression. John Willey and Sons, New York.

Kennedy E. 2003. Qualitative Measures of Food Insecurity and Hunger. In Proceeding, Measurement and Assessment of Food Deprivation and Undernutrition. International Scientific Symposium. Rome, 2628 Juni 2002.

Maxwell D, Clement A, Levin C, Margaret A, Sawudatu Z, \& Grace ML. 1999. Alternative Food Security Indicators: Revisiting the Frequency and Severity of Coping Strategies. Food Policy, 24 (4), 411429.

Nainggolan K. 2008. Kebijakan dan Strategi Ketahanan Pangan untuk Pembangunan Daerah. Makalah Rapat Bidang Pangan dan Agribisnis Kadin Indonesia, Jakarta 22 Januari 2008.

Smith LC. 2003. The Use of Household Expenditure Surveys for The Assessment of Food Insecurity. Proceedings Measurement and Assessment of Food Deprivation and Undernutrition. International Scientific Symposium, Rome 26-28 June 2002.

[TKPK] Tim Koordinasi Penanggulangan Kemiskinan (TKPK). 2009. Evaluasi Awal Perkembangan Penduduk Miskin Tahun 2009. Menteri Koordinator Bidang Kesejahteraan Rakyat, Jakarta. http:// tpkri.org. 